\title{
FORUM
}

Submitted 07.31.2017. Approved 12.26.2017

Evaluated through a double-blind review process. Guest Scientific Editors: Marina Heck, Jeffrey Pilcher, Krishnendu Ray, and Eliane Brito

DOI: http://dx.doi.org/10.1590/So034-759020180307

\section{LEGITIMACY AS A BARRIER: AN ANALYSIS OF BRAZILIAN PREMIUM COCOA AND CHOCOLATE LEGITIMATION PROCESS}

\author{
Legitimidade como uma barreira: Análise do processo de legitimação do cacau \\ e chocolate premium brasileiros
}

\author{
Legitimidad como una barrera: Un análisis del proceso de legitimación del \\ cacao y del chocolate premium brasileños
}

\begin{abstract}
How can a product be legitimated when the legitimation process includes another legitimate product as a barrier? To address this question, we conducted a process theorization through in-depth analysis of interviews and newspaper articles in the context of Brazilian premium cocoa and chocolate markets. We found that the legitimation process involving the interaction of different actors focused on building cultural-cognitive legitimacy was supported, in particular, by normative legitimacy. In this process, media appears as an important market ally in educating consumers. We used institutional theory to show that it is essential to address other legitimate products and the interaction of actors to understand the legitimation process.
\end{abstract}

KEYWORDS | Legitimation, legitimacy barrier, market development, premium chocolate, premium cocoa.

\section{RESUMO}

Como um produto pode ser legitimado quando seu processo de legitimação inclui outro produto legítimo como barreira? Para responder a essa pergunta, realizamos uma teorização de processo utilizando artigos de jornal e entrevistas em profundidade no contexto dos mercados brasileiros de cacau e chocolate premium. Descobrimos que o processo de legitimação envolve a interação de diferentes atores focados na construção de legitimidade cultural-cognitiva, apoiada principalmente pela legitimidade normativa. Nesse processo, a mídia aparece como um importante aliado do mercado, educando os consumidores. Utilizamos teoria institucional para mostrar que abordar outros produtos legítimos e a interação dos atores é essencial para entender o processo de legitimação.

PALAVRAS-CHAVE / Legitimação, barreira de legitimidade, desenvolvimento de mercado, chocolate premium, cacau premium.

bruno.sutil@gmail.com

ORCID: 0000-0002-6934-5897

MARIA CAROLINA ZANETTE ${ }^{2}$

m.zanette@eslsca.fr

ORCID: 0000-0001-9245-8710

${ }^{1}$ Fundação Getulio Vargas, Escola de Administração de Empresas de São Paulo, São Paulo, SP, Brazil

2Ecole Superieure Libre des Sciences Commerciales Appliquees, Paris, France

\section{RESUMEN}

¿Cómo puede un producto ser legitimado cuando su proceso de legitimación incluye otro producto legítimo como barrera? Para responder esta pregunta, realizamos una teorización del proceso utilizando artículos de periódicos y entrevistas en profundidad, en el contexto de los mercados brasileños de cacao y de chocolate premium. Descubrimos que el proceso de legitimación involucra la interacción de diferentes actores enfocados en la construcción de la legitimidad cultural-cognitiva, apoyada principalmente por la legitimidad normativa. En este proceso, los medios de comunicación aparecen como importantes aliados del mercado al educar a los consumidores. Utilizamos la teoría institucional para mostrar que abordar otros productos legítimos y la interacción de los actores es esencial para entender el proceso de legitimación.

PALABRAS CLAVE / Legitimación, barrera de legitimidad, desarrollo de mercado, chocolate premium, cacao premium. 


\section{INTRODUCTION}

How is legitimacy built? What factors can influence this process? Who are the actors involved? Existing literature has examined questions such as these over time. Much of the research involving legitimacy relies on Suchman's (1995) concept and on Scott's (2008) three logical elements that comprise institutions. These are the regulative, normative, and culturalcognitive "pillars" that constitute the essential elements of an institutional structure.

Previous research on the subject has explored the creation and the change of markets. Some examples include the studies of stigmatized industries (Humphreys, 2010b), marginalized consumers (Scaraboto \& Fischer, 2013), the connection between consumers and brands (Kates, 2004), the creation of a specific market (Humphreys, 2010a), and the changes in strategic orientations (Press Arnould, Murray, \& Strand, 2014). However, little is known about how actors build legitimacy when it involves confronting another legitimacy already established. In other words, how can a product be legitimated when it includes, in addition to the complex legitimation process itself, another legitimate product as a barrier?

Previous works on food studies have approached the idea of legitimacy concerning gourmet and artisanal food culture (Dória, 2014; Johnston \& Baumann, 2010; Watson \& Caldwell, 2005). Following this concept, we chose the context of Brazilian premium cocoa and chocolate market to illustrate how this process occurs. We discuss how the legitimation process takes place when there is already a competing legitimacy in the market. Our focus is on understanding the multiple actors involved in this process, as well as their interactions.

We also explore how a legitimation process takes place through the interaction of several actors who share common cultural-cognitive traits regarding an established and institutionalized ethos. Furthermore, our work contributes to explore the development of Brazilian products and ingredients in a market traditionally characterized by a colonialist taste-structure, which tends to reject what is national in favor of what is foreign (Dória, 2014).

For this purpose, we present a multi-method qualitative study that provides a process theorization of institutional change (Giesler \& Thompson, 2016). By exploring the views, actions, and narratives of actors involved in the legitimation process, we showcase the emergence of different types of legitimacy for the given product. The focus of analysis lies in the cocoa and chocolate production mostly in Southern Bahia, where cocoa production is traditional and has deep historical roots.

\section{Legitimacy and market dynamics}

Institutions are social structures that represent order and patterns, providing meaning and stability to social life (DiMaggio \& Powell, 1991; Scott, 2008), whereas legitimacy is "a generalized perception or assumption that the actions of an entity are desirable, proper or appropriate within some socially constructed system of norms, values, beliefs, and definitions" (Suchman, 1995, p. 574). Legitimacy is a mechanism for social reality construction, since its achievement is a "process in which widely shared cultural beliefs from the surrounding society create strong expectations for what is likely to occur in the local situation" Johnson, Dowd, \& Ridgeway, 2006, p. 7).

Regarding the relationship between the concepts above, three types of legitimacy support institutions (Humphreys, 2010a, 2010b; Scott, 2008; Suchman, 1995): regulative, normative, and cultural-cognitive. Regulative legitimacy regards laws and rules, being legally sanctioned by an organization such as the government (Humphreys, 2010b; Press et al., 2014; Scott, 2008). Normative legitimacy refers to social obligations (Scott, 2008); it is the degree of consensus within a system of norms and values (Humphreys, 2010b). Cultural-cognitive legitimacy relates to common beliefs and cultural support (Scott, 2008); it is what a community takes for granted (Humphreys, 2010a, 2010b; Scott, 2008; Suchman, 1995).

Many consumption studies using institutional theory have approached the legitimacy construction (Humphreys, 2010a, 2010b, 2014; Kates, 2004; Press \& Arnould, 2011; Press et al., 2014; Scaraboto \& Fischer, 2013). These works have made room in the field for the use of institutional theory, yet some issues still deserve further investigation. To do so, we will examine some of these works.

Humphreys (2010a, 2010b) explored how legitimacy is historically established based on discourse changes and market creation and development over time. For this purpose, she analyzed the three types of legitimacy in the stigmatized casino industry. Humphreys (2010b) focuses on the crucial role played by media in the process of legitimation and finds that it shapes consumer's perception of legitimacy. Her discoveries increase the knowledge about the power of particular actors in the process, which is especially relevant for showing how they build different types of legitimacy.

By examining changes in the strategic orientation in an agricultural commodity market, Press et al. (2014) address the issue of ideology and legitimacy by investigating how tensions in culture affect regulation. The premium chocolate market in Brazil faces a similar scenario in which the new market of national 
premium chocolate competed with the already established and legitimized "Belgian chocolate," considered a synonym of high quality in Brazil (a cultural point).

While Humphreys (2010b) analyzed a legitimation process that presented no competing industry (focusing on the change of mindset and regulation towards casino gambling), Press et al. (2014) focused on ideologies sustaining different legitimate production logics. They pointed out that the legitimate chemical production is a barrier to the growth of the organic product market, although they did not explain how this market could overcome the challenge. None of these works addresses the point of how a product/industry can legitimate itself when the legitimacy of another product/industry emerges as a barrier. Therefore, for a better understanding of the legitimation process, it is essential to explore how to overcome the barrier of building legitimacy against a legitimacy already established.

Likewise, in both works, the processes studied involved the participation and interaction of different actors. However, they fail to address how the various actors participating in the process interact to build legitimacy, by only exploring the performance of separate actors of the process. Therefore, in addition to better understanding the concurrent legitimacy as a barrier, we emphasize how multiple actors interact in the legitimation process.

The food universe provides a fertile field for working with legitimation. For instance, in the 1980s, French chocolatiers had to reinvent themselves as artisanal by enhancing connoisseurship, taste, and accuracy to attract a rising middle-class and not lose the domestic market to the international one (Watson \& Caldwell, 2005). Connoisseurship is one of the basis of the concept of legitimacy, supporting the construction of cultural-cognitive legitimacy (Quintão \& Brito, 2016), since it relates to taste structures. These, in turn, sustain the growing demand for artisan, gourmet, and specialty products (Johnston \& Baumann, 2010).

As can be seen, the investigation of contexts related to the food universe can be an excellent material for exploring the issues raised during the legitimation process. Therefore, we examine the context of Brazilian premium cocoa and chocolate market to answer the questions previously raised.

\section{DATA AND ANALYSIS}

To achieve our goal, we collected data from newspaper articles, participants' considerations, and interviews with workers of Brazilian premium cocoa and chocolate market. We underline the importance of newspaper articles because they portray the general view on the market, reflecting the opinions that come from different groups and actors (Humphreys, 2014).

To gather the data from newspapers, we determined a set of keywords (see Exhibit 1) related to cocoa and chocolate market and production to generate an article database. We collected the data from the websites of the three most relevant Brazilian newspapers, resulting in 613 selected articles.

\section{Exhibit 1.Description of newspaper articles' research}

\begin{tabular}{l|c|c|c}
\hline & \multicolumn{3}{|c}{ Number of articles per newspaper } \\
\hline Keywords & $\begin{array}{c}\text { Valor } \\
\text { Econômico }\end{array}$ & $\begin{array}{c}\text { Folha de } \\
\text { São Paulo }\end{array}$ & $\begin{array}{c}\text { Estado de } \\
\text { São Paulo }\end{array}$ \\
\hline Cocoa market & 31 & 7 & 26 \\
\hline Cocoa exportation & 11 & 6 & 52 \\
\hline Cocoa production & 65 & 56 & 47 \\
\hline Chocolate production & 31 & 21 & 50 \\
\hline Callebaut chocolate & 1 & 12 & 6 \\
\hline Gourmet chocolate & 12 & 13 & 24 \\
\hline Chocolate market & 40 & 17 & 85
\end{tabular}

We also conducted seven in-depth interviews (see Exhibit 2) to better understand the actor's participation in the legitimation process. In addition, following Kozinets (2002), we used the notes made by a participant of the Chocolat Bahia Festival 2017 and the Naturaltech Fair 2017.

\section{Exhibit 2. Description of interviews}

\begin{tabular}{c|l}
\hline Interview & Description \\
\hline 1 & $\begin{array}{l}\text { A chocolate specialist and a cacao specialist from a } \\
\text { fine/premium chocolate multinational }\end{array}$ \\
\hline 2 & $\begin{array}{l}\text { Former agriculturist at Executive Commission of the } \\
\text { Specialist at a small Brazilian premium chocolate } \\
\text { factory }\end{array}$ \\
\hline 3 & $\begin{array}{l}\text { A crop specialist at Cocoa Innovation Center (CIC), a } \\
\text { small Brazilian premium chocolate producer }\end{array}$ \\
\hline 5 & $\begin{array}{l}\text { Cocoa farmer with bad practices (low quality cocoa) } \\
\text { Cocoa farmer and president of a Premium chocolate } \\
\text { association }\end{array}$ \\
\hline 5
\end{tabular}


Following Giesler and Thompson (2016), we coded our data considering the events, activities, and choices to describe a changing process that configures a type of institutional transformation. Thus, we used an interpretive and iterative approach following other consumer research studies (Humphreys, 2010b, 2014; Scaraboto and Fischer, 2013). The data were read and coded, then axially coded (Corbin \& Strauss, 2008), wherein each data source had two encoders.

\section{FINDINGS}

In this section, we first contextualize the decline of Brazilian cocoa production and the emergence of Belgian chocolate in the country. Then, we discuss the three thematic categories ("emerging as premium," "tree-to-bar production," and "the value of origin") that emerged from our analysis. Within each theme, we discuss the legitimacy construction on how the actors who participated in the process interacted in a way that contributed to the occurrence of the process.

\section{Brazilian cocoa production}

The history of cacao in Southern Bahia goes back to the $18^{\text {th }}$ century when cacao was brought to the region and cultivated in small properties. In the second half of the $19^{\text {th }}$ century, cacao production attracted families from other areas and countries. Since then, cacao monoculture began to prosper in Southern Bahia (Rocha, 2008).

In the $20^{\text {th }}$ century, a series of events took place in the region, such as plant diseases in 1957, the entry of other countries in the cocoa market, and the financial indebtedness of cocoa farmers. In the late 1980s, Witches' Broom Disease (WBD) devastated the Brazilian cocoa production, which was the second largest in the world at the time. WBD is caused by fungus Crinipellis perniciosa, which attacks the fruits, buds, and flower bulbs of the cacao plant, usually causing its death (Caldas \& Perz, 2013). Cacao crops were severely devastated; cocoa farmers went bankrupt, and the country's production collapsed (Miragaia, 2015). Consequently, Brazilian cocoa entered a process of losing force in both international and domestic cocoa markets. Subsequently, Brazilian production began to increase again only in 2004 (Euromonitor, 2017) after joining CEPLAC's (Comissão Executiva do Plano da Lavoura Cacaueira-a government entity dedicated to the development of cacao production) efforts in creating more resistant crops for cacao producers. Figure 1 displays a timeline of the main events in the history of cacao in the region.

\section{Figure 1. Important events of cocoa history in Brazil}

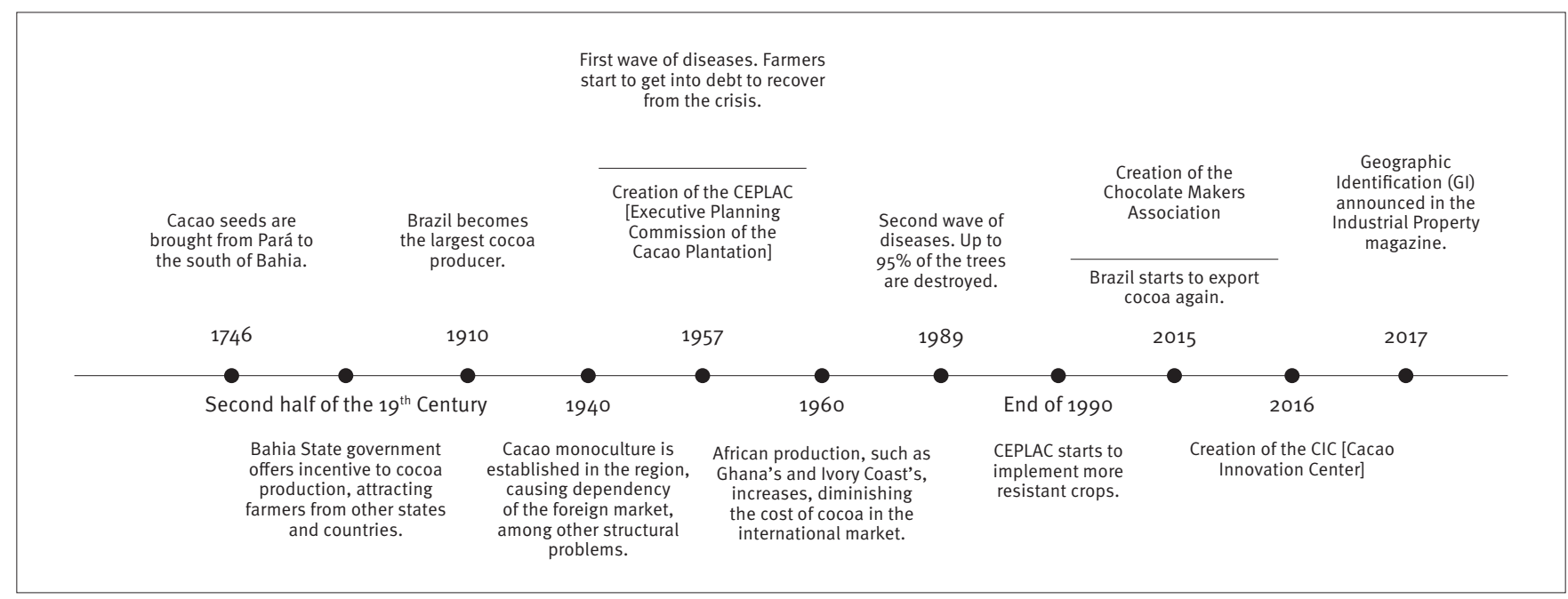

As for the chocolate, until the late 1990s, Brazilian industry produced chocolates mainly to the mass market, in which consumers tended to buy nationally manufactured consumer goods. A change in the consumption pattern occurred in the $2000 \mathrm{~s}$ when the purchasing power in Brazil increased substantially. For instance, the percentage of individuals from socio-economic classes A, B, and C increased from 49\% in 2003 to $61 \%$ in 2012 (Classe C sustentará aumento de 40\% do PIB até 2020, 2012). Such a change fomented more "sophisticated" consumption patterns, that is, tastes that were already part of the elite's habits, such as consuming imported goods as a form of distinction (Dória, 2014). Therefore, foreign companies, such as Barry-Callebaut and 
Lindt \& Sprüngli, decided to invest in the country. Although the companies are not Belgian, it has the image of Belgian chocolate that is highly associated with the premium or gourmet market segment (Baixo teor de cacau leva indústria a incluir mais açúcar e gordura, 2014).

In this context, foreign products in the country are a reference in quality and imply a significant challenge to the Brazilian cocoa (i.e., chocolate) search for legitimacy, fighting against the preference in the premium segment for Belgian chocolates, which is already legitimized.

\section{Emerging as premium: The search for legitimation in a growing market segment}

During the process of recovering from the crisis, cocoa farmers started investing in premium cocoa production, following a recommendation from CEPLAC. The quotes below show that CEPLAC's decision was based on the price difference between premium and commodity cocoa; it was also based on the fact that the premium segment presents an increasing demand. In the first quote, a former CEPLAC member describes the institution's position regarding the cocoa farmer's recovery, while, in the second one, a cocoa farmer discusses the increasing demand for premium products.

[When] I was at CEPLAC, they argued that Brazil should produce special cocoa to sell it for a special price. You would sell only well-selected, and well-fermented cocoa with a high-quality standard and the company will pay you for it. (Interview 2)

There is a good part of the community [...] that sees fine chocolate production as a solution. I, particularly, think that for our region in [Southern] Bahia, which operates under the cabruca system [a less profitable type of crop], this is the final solution because fine cacao market will remain as a good market. (Interview 7)

Therefore, the premium market sets an opportunity to leverage the entire value chain, which refers to the integrated system of production and distribution of a given product (Gereffi, Humphrey, \& Sturgeon, 2005) to position it in the international market. Brazil's favorable conditions for this opportunity include the history and tradition of cacao farming, the know- how in chocolate production, and a consumer market that has an increasing purchasing power. For example,

"Brazil has the elements to dominate the premium market. The country has production, mills, industries and consumption. This scenario does not exist anywhere else in the world," according to Patricia [executive director of Agrícola Conduro, a cocoa processing company]. She also said that, in recent years, changes have been made in the cocoa and chocolate chain in Southern Bahia, focusing on the long-term. (Turtelli \& Pakulski, 2016)

We have the tradition; we have a history because this culture has been here for more than 200 years. Well, I think we have several factors, [and we just have to] know how to communicate it to value ourselves and enter this high-quality market. (Interview 3)

Despite the favorable conditions for the development of the premium segment in the country, the legitimation of Brazilian premium chocolate faces a challenge regarding a cultural understanding of the market: Brazilian consumers associate foreign products with premium products (Dória, 2014). As the media coverage indicates, consumers view European brands such as Lindt, Callebaut, and Belgian chocolates as synonyms for premium or gourmet products. The quotes from newspaper articles below showcase that Brazilian chocolate producers see that as a challenge they need to overcome.

Today only $2 \%$ of Harald's revenue (the fourth largest Brazilian chocolate company) comes from $100 \%$ national fine chocolates. According to the company's founder, Ernesto Neugebauer: "We're attracting clients by the taste, giving them the chocolate and making them try it. Otherwise, as far as premium products are concerned, customers just want Belgian chocolates." (Baixo teor de cacau leva indústria a incluir mais açúcar e gordura, 2014)

For the final consumer, Cíntia Lima (a chocolatier) sees education as today's biggest challenge for the insurgency of the Brazilian chocolate. "The customer comes to my store and wants Belgian 
chocolate. I've changed from Belgian to Brazilian chocolate because I came here [to Bahia] to find this good quality cocoa. I tell this to my consumers because they need to know that." (Boni, 2014)

Therefore, the media acknowledges that Brazilian consumers see Belgian chocolate as a symbol of high-quality products, emphasizing the cultural-cognitive legitimacy of the foreign product. Hence, Brazilian producers struggle to level their product with Belgian chocolate. In this context, the striving for cultural-cognitive legitimacy is an essential goal in the process of confronting the status-quo.

The media also appears as an important ally to premium chocolate producers, by elaborating articles about the quality of Brazilian cocoa and chocolate and how similar they are to, or even better than, Belgian products. It comes up as an actor with the power to educate and influence consumers through the diffusion of information. The next quote is an example of a newspaper article that emphasizes the quality of Brazilian products by associating it with João Tavares-an internationally awarded Brazilian producer, who belongs to the third generation of one of the largest cacao producing families in Brazil:

“The inferiority complex is over. Now people are proud to buy Brazilian products. Just look at this festival," João Tavares says. He is a gourmet cocoa producer, who has won awards at the Salon $d u$ Chocolat, one of the most important fairs in the world. [...] Being from a farmer's family, he decided to change the production system ten years ago and to invest in a high-quality cocoa instead of a commodity cocoa, by improving the harvesting process. Because of the quality of his products, he has gained markets both inside and outside the country. (Miragaia, 2016)

The excerpt shows how the media endorses an important Brazilian cocoa producer that has a product recognized worldwide for its high quality. The phrase "the inferiority complex is over" introduces the fact that, now, there is a Brazilian premium product that is as good as the foreign one. The fact that the article mentions the producer's success inside and outside the country relates to the legitimating process of the Brazilian product in comparison to a foreign one. Therefore, the media is using the foreign product's legitimacy as an indicator to attest the high quality of the Brazilian product.
The media connects cocoa and chocolate so that the idea consumers have about the former can influence the image building of the latter, which implies that if Brazilian cocoa achieves legitimacy as premium cocoa, then it will be able to benefit from its image. Therefore, the interaction between media and producers contributes to the construction of cultural-cognitive legitimacy of Brazilian cacao and chocolate in the premium segment, and simultaneously fights the Belgian chocolate legitimacy.

\section{Tree-to-bar production: Cacao processing as an element of legitimacy}

The relation between cocoa quality and chocolate quality used in the latter's production is a major theme in the data regarding legitimation. The following example from a newspaper article shows the media's effort to point out the importance of processing for the quality of a product-even though the description is not accurate. The excerpt is about Diego Badaró and Frederick Schilling, owners of the AMMA (a premium organic chocolate brand), and how they produce high-quality cacao and chocolate by focusing on mastering the production process.

[Schilling and Badaró] correctly understood that the fermentation and the drying process are the most important stages in the chocolate production. These processes control the taste. [...] [They] strictly comply with all the stages of the process during the fermentation, which is slow and requires a strict temperature control. At the end of this phase, comes the drying process. [...] [They] adjust the final stage of the product according to the characteristics of each bean. After roasted and ground the cocoa begins to turn into chocolate. The slow process of conching is a crucial detail, in which the chocolate is stirred by shell-shaped spatulas: the chocolate and the sugar mixture is rotated without interruption for about 72 hours until all the acids evaporate and the texture becomes creamy. Then, the chocolate comes out ready to be packed after the tempering and the crystallization process. (Bertolino, 2010)

From the above excerpt, it is evident that the relation between cocoa and chocolate quality in every stage of production is critical. The media highlights specific process requirements as a standard for premium chocolate: there is no regulation for what 
is considered to be premium chocolate; it has just instructions on how to produce it, which configures a normative legitimacy.

In line with the emphasis on the processing presented by the media, the following quote of a small premium chocolate producer shows how important these technical aspects are to the quality of the final product.

The bean processing really matters. If it is well fermented, the way it is cut, if the fruit is broken in the right direction. [...] It is something really technical. If it is stirred up every hour in order to be able to have a uniform fermentation. (Interview 6)

Thus, carrying out an excellent processing of a good cacao bean is critical when producing premium chocolate. In this context, we introduce and highlight the concept of "beanto-bar," which is a method of chocolate production in which the chocolate maker has control over the entire production chain. The producers are responsible for almost up to the final stage of production-transforming raw material into chocolate in an artisanal way.

When emphasizing the importance of processing, the media approaches the concept of "bean-to-bar" as a consequence of harvesting. The following quote shows the straight relationship between quality and processing in the bean-to-bar method.

The difference [of bean-to-bar chocolates] when compared to conventional chocolates is remarkable. In the industry, chocolates are made from a mixture of cocoa beans of different origins with additives to standardize the flavor. Even some of the so-called fine chocolates are less complex than the bean-to-bar. (Mesquita, 2016)

Consequently, a new definition emerges when the media enlightens its readers about the connection between the beanto-bar process and quality. The bean-to-bar concept and the idea of the chocolatier mastering the entire chocolate process comes from chocolate makers in California; they have been manufacturing their product based on it for more than a decade (Mesquita, 2016). However, chocolatiers in the United States and European countries must buy the beans from producing countries. That is precisely why this process is called "bean-tobar": the chocolate makers do not own the farms, but they seek to buy quality cocoa beans of specific farmers from producing countries.
In an attempt to leverage the cocoa and chocolate production in Brazil, producers started to follow the bean-tobar practices. It was possible because of the country's favorable conditions mentioned in the previous section, which gave the opportunity to Brazilian chocolate producers to create their analogous concept, called "tree-to-bar." Following this concept, the chocolate maker owns the cacao farm as well as the chocolate production, as reported below by a cocoa farmer:

We had a bold posture because copying what is done in California did not satisfy us. Our case is not "bean-to-bar," it is "tree-to-bar;" we had the trees, we had the cacao in our land. We had some knowledge about our cocoa. (Interview 5)

The quote shows that Brazilian producers are trying to build their product's legitimacy by combining two strategies: (1) associating the product with a highly valued production process, and (2) crafting a new concept to define a process that better matches the unique condition of the Brazilian production chain. The development of this combination is an attempt to add the cultural-cognitive legitimacy to a characteristic that is already related to the normative legitimacy, since it is a signification that is being socially constructed (Scott, 2008). The media enters this equation, once again, as a way of connecting the general public to what producers are doing.

Therefore, to legitimate Brazilian chocolate within the premium sector, media and producers have been associating it with a particular processing connected to a high-quality notion. Moreover, it is important to highlight that the media does not associate Belgian chocolate to "bean-to-bar" production; it just mentions that consumers in Brazil see it as a premium product of great value. Therefore, the legitimation process involves ascribing meaning to Brazilian chocolate that are unrelated to Belgian chocolate in a mixture of normative and cultural-cognitive legitimacy.

\section{Value of origin: The provenience of the ingredient as a synonym for quality}

In the last two sections, we saw how Brazilian cocoa and Brazilian chocolate search for legitimation on a premium market dominated by common sense that "Belgian chocolate" is a synonym for "chocolate of high quality." In this process, media appears as an ally to premium cacao and chocolate producers by showing its audience the existence of high-quality products 
from Brazil (both cacao and chocolate) and by connecting cocoa processing (a premium product feature) and chocolate to those Brazilian products. In line with these two platforms for building legitimacy, there is a search for certifications that attests the origin of the product.

Origin (the place where a product comes from) is a feature that can be used to designate quality. In the premium chocolate market, it can be seen in "Belgian chocolate" and "Swiss chocolate." Accordingly, actors seek a certification that attests the origin of the Brazilian product. However, in this case, origin certification is being pursued not for the chocolate, but for the cocoa. Obtaining this certification could contribute to the building of a good image for Brazilian cocoa, as the following quote states: "The government also seeks to obtain, in 2014, the registration of the product's geographical indication (GI) in Southern Bahia. The document guarantees identity, reputation, and value to cocoa" (Borlina Filho, 2012).

The main difference is that the actors seek to obtain a cocoa certification-in this case, GI, a certification used to identify the origin of products or services from a place that presents a particular characteristic or quality due to its origin (INPI, 2017), instead of a chocolate certification. Since the former is the main ingredient to produce the latter, a cacao with the quality approved insures legitimacy to the chocolate.

The purpose of obtaining a cacao certification instead of a chocolate certification is directly related to the development of the Brazilian cocoa production, which is still recovering from the crisis caused by WBD. Thus, achieving cocoa legitimation by attesting its quality through origin certification can boost both cocoa and chocolate production, leveraging the entire value chain through normative legitimacy.

Certifications and accreditations relate to the normative legitimacy construction (Scott, 2008); they state how things should be, creating a standard. The origin certification imposes a norm that producers must follow so that their products are considered high-quality products. Thus, the certification influences Brazilian chocolate legitimacy by associating it with cocoa from a high-quality origin, directly confronting the notion associated with Belgian chocolate.

Although the origin certification pursued is not for the "Brazilian" cacao, but for cacao from specific regions of the country (such as Southern Bahia), it still represents a conflict with Belgian chocolate in the domestic market.

One characteristic that is related to this certification of quality is the tradition of a producing region. In Brazil, some products have already had their quality recognized according to its origin. The quote below illustrates this situation.
The cocoa Geographical Indication must have a tradition related to the region. [...] Here in Brazil, there's the cachaça from Bahia seal in Bahia, there is the cachaça from Paraty seal in Rio de Janeiro, there is the Pampas' meat seal in Rio Grande do Sul, and other seals, like the Canastra cheese seal. (Interview 5)

As the quote shows, recognition is related to a cultural aspect. Thus, normative legitimacy is associated with the culturalcognitive legitimacy once the tradition in crafting the product becomes a symbol that shapes the meaning attributed to the product. Therefore, while the place of origin grants culturalcognitive legitimacy, the certification allows, mainly, normative legitimacy.

In the search for the accreditation, the associations of producers are the leading actors. These associations, besides supporting the producers' development, also push to legitimate Brazilian cocoa and chocolate. Its actions are closely related to the achievement of normative legitimacy, and the struggle to obtain the cacao origin certification is an example of that. The quote below illustrates how associations act to guarantee a production with high-quality standards. Considering the connection between the Brazilian premium chocolate production and premium cacao production, even though the interviewee mentions only chocolate consumption, it is considered as the result of the premium cacao production.

If you come from another place and buy a chocolate that you like, you'll buy it again, but if you buy a chocolate and you hate it, you think “Geez, I won't buy it anymore." Then you already generalize. "I bought this one, this is my impression of the Southern Bahia chocolate, and it is awful." That's why they are trying to join efforts so the Association will be able to define: what are the quality standards? (Interview 3)

As illustrated above, the association is the actor concerned about the standardization of the regional production to guarantee the required quality to the cacao and, consequently, to the premium chocolate produced after it. In this context, the certification appears as a way to make this connection clear to the market, by associating the origin of a certified premium cacao with the quality of the premium chocolate. The quote below exemplifies this connection by emphasizing that cacao must achieve some quality standards to be certified. 
The geographical indication of Southern Bahia will perform the role of linking the certification to the material of a certain quality. There are regulations for its use and $\mathrm{CIC}$ [Cacao Innovation Center] will be responsible for examining whether or not they are appropriate to the regulation (Interview 3).

Thus, these associations engage with other institutions (in this case, $\mathrm{CIC}$, an organization dedicated to building knowledge about quality cocoa and chocolate focusing on productivity, quality, and traceability of cocoa beans [Fórum do Cacau, 2017]) to regulate the quality specifications that the product must contain. This example shows that there is also a regulatory structure behind the process of validating the certification.

As in the case of the emergence as a premium product and the connection of the "tree-to-bar" to quality, the media also plays a significant role in disseminating information about the certification of origin, its importance, and its relation to the quality of a product. The quote below (from media) highlights how the certification of origin is associated to quality.

In practice, [GI certification] means that the whole agro-food chain tends to improve. The explanation is simple: in the process to obtain the certification, producers are obliged to become members (GI is granted only to companies) and end up enhancing the processes and improving the quality of the final product. (Orenstein, 2014)

As the quote shows, media is acting in line with producers and associations by educating consumers on the Brazilian product to legitimize it. The achievement of the cacao's certification of origin connects to the construction of a differentiation trait for the Brazilian product (both premium cacao and chocolate). It aims to associate the origin of the ingredients to quality through cultural status and standard regulations. The purpose of highlighting the certification to the consumer is to attest the association between the origin and the quality.

Thus, similar to what happens in the case of the "treeto-bar" process, the link that the associations and the media are trying to consolidate-between the origin certification and the quality-also contributes to the legitimation process by creating new meanings associated with cacao and chocolate. The difference is that Belgian chocolate is recognized by its origin, which leads to a confrontation of meaning and symbolism of the legitimation process. Therefore, due to the battle of meanings, the media, more than ever, plays a crucial role in consumer education. Again, the process comprises a blend of normative and culturalcognitive legitimacy, except this time, it is supported by regulative standards that validate the normative pillar.

\section{DISCUSSION}

In this study, we examined how the legitimation process occurs when a concurrent legitimacy appears as a cultural barrier. We analyzed how the different actors involved contribute to the process; for this purpose, we considered the cocoa and chocolate production in Brazil.

Brazilian cocoa and chocolate producers face the challenge of legitimizing their product in a market segment that values Belgian chocolate as "premium." In this process, actors are investing mainly in constructing cultural-cognitive legitimacy, greatly supported by the elements related to normative legitimacy and, sometimes, to regulative legitimacy. The findings are summarized in Exhibit 3.

\section{Exhibit 3. Compilation of findings}

\begin{tabular}{|c|c|c|c|}
\hline & $\begin{array}{l}\text { Type of } \\
\text { legitimacy }\end{array}$ & Platform & $\begin{array}{l}\text { Actors } \\
\text { involved }\end{array}$ \\
\hline $\begin{array}{l}\text { Emerging as } \\
\text { premium: the } \\
\text { search for } \\
\text { legitimation in } \\
\text { (and through) a } \\
\text { growing market } \\
\text { segment }\end{array}$ & $\begin{array}{l}\text { Cultural- } \\
\text { cognitive }\end{array}$ & Market & $\begin{array}{l}\text { Cocoa and } \\
\text { chocolate } \\
\text { producers; } \\
\text { Media }\end{array}$ \\
\hline $\begin{array}{l}\text { Tree-to-bar } \\
\text { production: } \\
\text { cocoa } \\
\text { processing as } \\
\text { an element of } \\
\text { legitimacy }\end{array}$ & $\begin{array}{l}\text { Cultural- } \\
\text { cognitive; } \\
\text { Normative }\end{array}$ & Process & $\begin{array}{l}\text { Cocoa and } \\
\text { chocolate } \\
\text { producers; } \\
\text { Media }\end{array}$ \\
\hline $\begin{array}{l}\text { Value of origin: } \\
\text { ingredient } \\
\text { provenience as } \\
\text { a synonym for } \\
\text { quality }\end{array}$ & $\begin{array}{l}\text { Cultural- } \\
\text { cognitive; } \\
\text { Normative; } \\
\text { Regulative }\end{array}$ & Certification & $\begin{array}{l}\text { Associations; } \\
\text { Media; } \\
\text { Regulative } \\
\text { institutions }\end{array}$ \\
\hline
\end{tabular}

Three platforms, which are part of the value chain that has been used, influence Brazilian chocolate and cocoa legitimacy as a premium product: market, process, and certification. Each platform relates to the different interactions between actors and the reinforcement of various types of legitimacy. The market 
platform is related to the decision of investing in the premium segment (in opposition to mass market) to develop the Brazilian product. This context initiates the process of challenging Belgian chocolate's position and legitimacy. For Brazilian consumers, its legitimacy is mainly cultural-cognitive, since there is a common belief that constitutes the symbolism and the meanings (Scott, 2008) relating Belgian chocolate as a synonym for "premium." In an attempt to confront this common belief, media and producers interact towards promoting the Brazilian product as being (at least) equal to its foreign competitor. Media connects consumers and producers, differentiating the national premium cacao from the commodity cacao production.

In addition, by highlighting cultural aspects, the process platform indicates a mix of cultural-cognitive and normative legitimacy. The interaction between producers and media promotes the association between Brazilian chocolate quality to its production process. Producers attempt to connect normative legitimacy to the construction of cultural-cognitive legitimacy by promoting the processing as an important aspect to quality and by creating their own concept to differentiate their product: "tree-to-bar."

Similar to what happens in the market platform, the media appears as an ally that strives to educate consumers about the importance of processing in order to achieve quality. In addition, it associates this distinguished processing with Brazilian chocolate, creating meanings that relate to its high quality but does not relate to Belgian chocolate. Thus, as the media contributes to the construction of symbolical practices (Humphreys, 2010b), which are portrayed in association with the Brazilian product, it promotes cultural-cognitive legitimacy, and ends up boosting the reach of the producers' discourses by focusing on the characteristics of Brazilian products. This process occurs simultaneously as "the tree-to-bar" chocolate production is being developed in Southern Bahia, being an important tool to leverage the product's image to the consumers. Moreover, the process creates connoisseurship, since it is related to the consumers' symbolic and cultural capital acquisition (Quintão \& Brito, 2016) when educated by the media on the importance of processing for the quality of the product.

In the certification platform, there is an interaction between the associations, the media, and the regulative institutions. The associations in this context are very similar to the producers on the other platforms; however, it represents a corpus of producers that outline guidelines for the community to standardize the production. Furthermore, the three types of legitimacy reinforce each other. When associations seek certification, they seek normative legitimacy because their purpose is to link expectations (Scott, 2008) between origin and quality. Although the certifications are related to norms, the certification of origin, in particular, is also related to the cultural-cognitive and regulative types of legitimacy. In the first case, it happens because this certification involves the tradition and the recognition of the cultural environment, which contribute to the production of high-quality products. Thus, as it acquires the certification and consumers see it as legitimate, not only the accreditation is associated, but also the cultural symbolism that exists around the product's origin. In the second case, the regulative aspect emanates because, as in many certifications, it presents technical requirements that must be attested by an institution. Therefore, the recognition system that regulates high-quality products supports normative legitimacy. Media appears as the meeting point for associations, as the consumer and its educating role also remains intact: in all situations, the media explains the concepts, processes, and what should be valued. Therefore, those three actors' interaction contribute to the promotion of the three types of legitimacy; it emphasizes Brazilian cocoa and chocolate for having a unique feature, which significantly contributes to the legitimacy construction against Belgian chocolate.

The concomitant and constant leverage of these three platforms contribute to the construction of the Brazilian cocoa and chocolate legitimacy against its foreign competitors. As they interact, we can see that the main focus is on achieving cultural-cognitive legitimacy, as that is where the notion of acceptance is built. As Belgian chocolate is seen as a common symbol for quality, normative legitimacy appears to support the cultural-cognitive legitimacy construction. Similar to Humphreys (2010b), these are the two main legitimacy types that emerge within the legitimation process. However, while in Humphreys (2010b) normative legitimacy seems to be supported because of cultural-cognitive and regulatory legitimacy, in this case it is cultural-cognitive legitimacy that is supported by normative and regulatory legitimacy.

In Brazil, a food market is being created for premium chocolate. The legitimacy of Belgian chocolate is built mainly because it comes from abroad, and thus being valued more than the domestic products (Dória, 2014). To fight against that notion, the cultural-cognitive legitimacy is being pursued based mainly on the "raw" quality of premium Brazilian cocoa as an ingredient and other features that emerge from it, such as processing and certification. Different from what happens in the case of organic agriculture (Press et al., 2014), legitimacy is not being built based on a niche, but on the change of the legitimacy "pillars" of the same niche. In contrast, similar to this case, the motivation to build legitimacy is more financial and less ideological. Although the food market in Brazil is highly dispersed (Dória, 2014), the 
main objective seems to be leveraging the product so that it can help farmers recover from its former losses, and not to fight against the foreign foods that are dominating the domestic market.

Finally, ideas such as sustainability and "locavorism" (Johnston \& Baumann, 2010) are not present within the efforts to build legitimacy. As highlighted before, the main focus seems to be on emphasizing quality as an intrinsic feature of Brazilian cocoa and its importance for the chocolate production, while legitimacy for Belgian chocolate comes from symbolism, tradition, and colonization.

\section{CONCLUSION}

We have contributed to the literature of market creation and market development by analyzing how a product can build its legitimacy while confronting another. We argued that, in this process, the main focus is on achieving cultural-cognitive legitimacy. That is, when the process involves overcoming another type of legitimacy, achieving cultural-cognitive legitimacy is essential, since it is related to the idea of something that is taken-for-granted. However, the pursuit for cultural-cognitive legitimacy is greatly supported by normative legitimacy, which sometimes is reinforced by regulative legitimacy.

These findings suggest some practical implications. First, within this setting, producers and associations appear to be heavily dependent on the media's role as an ally to reach consumers. However, they could explore opportunities to have a more direct connection with them in order to have more control over the message that is being disseminated. Thus, they would be less vulnerable to possible changes in media's actions. Second, cocoa and chocolate productions still depend on initiatives to develop themselves. In their search for legitimation, producers and associations look mainly for cultural-cognitive and normative legitimacy platforms. They could also benefit from regulatory characteristics, which prevail as legitimate due to the support of the three types of legitimacy in stable social systems (Scott, 2008). Therefore, there is still space for a greater government interaction with the other platforms so that Brazilian cocoa and chocolate can be fully legitimized.

Our study presents some limitations that provide insights for future studies. Some of the questions that could be addressed are as follows: Who is the consumer in the middle of this process? How is he responding to it? It would be also interesting to verify the interference of cultural valorization related to nationality: When is the domestic product valued? When is the foreign product valued? A second line of research, more connected to food studies, could be used to better understand the circumstances and mechanisms that made possible the legitimation of the Belgian chocolate in the premium market segment in Brazil. Finally, future studies could also approach contexts in which the government has a stronger influence on the market: How does it take part in this process and how can a structure with stronger regulatory legitimacy facilitate (or hinder) this process? Understanding the questions addressed in this study and these other questions is very important to have a holistic view of the legitimation process, accessing it in many different ways.

\section{REFERENCES}

Baixo teor de cacau leva indústria a incluir mais açúcar e gordura. (2014, August 20). Folha de São Paulo. Retrieved from http://feeds.folha. uol.com.br/fsp/comida/181446-baixo-teor-de-cacau-leva-industriaa-incluir-mais-acucar-e-gordura.shtml

Boni, A. P. (2014, July 15). Fórum discute produção de cacau e chocolate $100 \%$ brasileiros em Ilhéus. Folha de São Paulo. Retrieved from http://www1.folha.uol.com.br/comida/2014/07/1491431-forumdiscute-producao-de-cacau-e-chocolate-10o-brasileiros-em-ilheus. shtml

Borlina Filho, V. (2012, September 09). Brasil quer fim do cacau importado em 5 anos. Folha de São Paulo. Retrieved from http:// www1.folha.uol.com.br/fsp/mercado/65319-brasil-quer-fim-docacau-importado-em-5-anos.shtml

Bertolino, C. (2010, March 11). Extremo, orgânico, gourmet. É o chocolate puro baiano, ôxente! Estado de São Paulo. Retrieved from http:// www.estadao.com.br/noticias/geral,extremo-organico-gourmet-e-ochocolate-puro-baiano-oxente,3650

Caldas, M. M., \& Perz, S. (2013). Agro-terrorism? The causes and consequences of the appearance of witch's broom disease in cacao plantations of southern Bahia, Brazil. Geoforum, 47, 147-157. doi:10.1016/j.geoforum.2013.01.006

Classe C sustentará aumento de 40\% do PIB até 2020. (2012, February 29). Estado de São Paulo. Retrieved from http://economia.estadao. com.br/noticias/negocios, classe-c-sustentara-aumento-de-40-dopib-ate-2020,104451e

Corbin, J., \& Strauss, A. (2008). Basics of qualitative research: Techniques and procedures for developing grounded theory. Thousand Oaks, CA: Sage Publications.

DiMaggio, P. J., \& Powell, W. W. (Eds.). (1991). The new institutionalism in organizational analysis. Chicago, IL: University of Chicago Press.

Dória, C. A. (2014). A formação da culinária brasileira. São Paulo, SP: Três Estrelas.

Euromonitor. (2017). Economies and consumers annual data. Retrieved from Euromonitor Passport Database.

Fórum do Cacau. (2017). Centro de Inovação do Cacau. Retrieved from http://forumdocacau.com.br/centro-de-inovacao-do-cacau/

Gereffi, G., Humphrey, J., \& Sturgeon, T. (2005). The governance of global value chains. Review of International Political Economy, 12(1), 78-104. doi:10.1080/09692290500049805 
Giesler, M., \& Thompson, C. J. (2016). A tutorial in consumer research: Process theorization in cultural consumer research. Journal of Consumer Research, 43(4), 497-508. doi:10.1093/jcr/ucw047

Humphreys, A. (2010a). Megamarketing: The creation of markets as a social process. Journal of Marketing, 74(2), 1-19. doi:10.1509/ jmkg.74.2.1

Humphreys, A. (2010b). Semiotic structure and the legitimation of consumption practices: The case of casino gambling. Journal of Consumer Research, 37(3), 490-510. doi:10.1086/652464

Humphreys, A. (2014). How is sustainability structured? The discursive life of environmentalism. Journal of Macromarketing, 34(3), 265-281. doi:10.1177/0276146714521238

Instituto Nacional da Propriedade Industrial. (2017). Guia básico de indicação geográfica. Retrieved from http://www.inpi.gov.br/menuservicos/indicacao-geografica

Johnson, C., Dowd, T. J., \& Ridgeway, C. L. (2006). Legitimacy as a social process. Annual review of sociology, 32, 53-78. doi:10.1146/annurev. soc.32.061604.123101

Johnston, J., \& Baumann, S. (2010). Foodies: Democracy and distinction in the American foodscape. New York, NY: Routledge.

Kates, S. M. (2004). The dynamics of brand legitimacy: An interpretive study in the gay men's community. Journal of consumer research, 31(2), 455-464. doi:10.1086/422122

Kozinets, R. V. (2002). Can consumers escape the market? Emancipatory illuminations from burning man. Journal of Consumer research, 29(1), 20-38. doi:10.1086/339919

Mesquita, R. (2016, April 20). Fantásticas minifábricas de chocolate em São Paulo. Estado de São Paulo. Retrieved from http://paladar. estadao.com.br/noticias/comida,fantasticas-minifabricas-dechocolate-na-cidade, 10000027287

Miragaia, M. (2015, October 25). Lojas usam cacau nacional em cenário dominado por chocolate importado. Folha de São Paulo. Retrieved from http://www1.folha.uol.com.br/saopaulo/2015/10/1697437lojas-usam-cacau-nacional-em-cenario-dominado-por-chocolateimportado.shtml
Miragaia, M. (2016, June 26). 'Acabou o complexo de vira-lata', diz produtor de cacau gourmet no Fartura. Folha de São Paulo. Retrieved from http://www1.folha.uol.com.br/comida/2016/o6/1785919-acabou-o-complexo-de-vira-lata-diz-produtor-de-cacau-gourmet-no-fartura.shtml

Orenstein, J. (2014, November 26). 0 gosto da origem. Estado de São Paulo. Retrieved from http://paladar.estadao.com.br/noticias/ bebida,o-gosto-da-origem,10000008266

Press, M., \& Arnould, E. J. (2011). Legitimating community supported agriculture through American pastoralist ideology. Journal of Consumer Culture, 11(2), 168-194. doi:10.1177/1469540511402450

Press, M., Arnould, E. J., Murray, J. B., \& Strand, K. (2014). Ideological challenges to changing strategic orientation in commodity agriculture. American Marketing Association, 78(6), 103-119. doi:10.1509/ jm.13.0280

Quintão, R. T., \& Brito, E. P. Z. (2016). Connoisseurship consumption and market evolution: An instituional theory perspective on the growth of specialty coffee consumption in the USA. REMark: Revista Brasileira de Marketing, 15(1), 1-15.

Rocha, L. B. (2008). A região cacaueira da Bahia-dos coronéis à vassoura-de-bruxa: saga, percepção, representação. Ilhéus, BA: Editus.

Scaraboto, D., \& Fischer, E. (2013). Frustrated fatshionistas: An institutional theory perspective on consumer quests for greater choice in mainstream markets. Journal of Consumer Research, 39(6), 1234-1257. doi:10.1086/668298

Scott, W. R. (2008). Institutions and organizations: Ideas, interests, and identities. Thousand Oaks, CA: Sage Publications.

Suchman, M. C. (1995). Managing legitimacy: Strategic and institutional approaches. Academy of management review, 20(3), 571-610. doi: $10.2307 / 258788$

Turtelli, C. \& Pakulski, L. (2016, November, 10). Mercado de chocolate premium cresce dois dígitos por ano no Brasil. Estado de São Paulo. Retrieved from http://economia.estadao.com.br/noticias/ geral,mercado-de-chocolate-premium-cresce-dois-digitos-por-anono-brasil,10000087542

Watson, J. L., \& Caldwell, M. L. (2005). The cultural politics of food and eating: A reader. Oxford, UK: Blackwell Publishing. 